\title{
Penguatan Kapasitas Kelompok Nelayan Wirausaha Mandiri melalui Transfer Teknologi Tepat Guna
}

\author{
Strengthening Capacity of Fishermen Entrepreneurial Self through Appropriate Technology Transfer \\ Ermayanti Ishak ${ }^{1 *}$ dan Roslindah Daeng Siang ${ }^{2}$
${ }^{1}$ Program Studi Manajemen Sumber Daya Perairan, Fakultas Perikanan dan Ilmu Kelautan Universitas Halu Oleo, Jl. HEA Mokodompit Kampus Bumi Tridharma Anduonohu Kendari 93232, (Phone/Fax : +62401393782), Hp. 081341794997; email: amekoe_81@yahoo.com
${ }^{2}$ Program Studi Agrobisnis Perikanan, Fakultas Perikanan dan Ilmu KelautanUniversitas Halu Oleo Jl. HEA Mokodompit Kampus Bumi Tridharma Anduonohu Kendari 93232, Hp. 085255350279; e-mail: roslindahds@yahoo.co.id

\begin{abstract}
ABSTRAK
Pengolahan hasil target tangkapan belum optimal dilakukan, apalagi pengolahan terhadap hasil sampingan tangkapan. Hal tersebut diakibatkan oleh lemahnya kapasitas kelompok nelayan, khususnya dalam pemanfaatan hasil laut di musim paceklik dan perolehan informasi pasar, sehingga sangat membutuhkan peningkatan ilmu pengetahuan dan transfer teknologi tepat guna. Tujuan penelitian: (1) menghasilkan kelompok nelayan terampil, kreatif dan inovatif dalam mengolah hasil laut; (2) menciptakan kelompok nelayan yang pandai berwirausaha dengan modal usaha murah, terjangkau dan berkelanjutan; (3) menjadikan kelompok nelayan sebagai pelopor usaha mandiri yang maju dan dikenal masyarakat sebagai produsen dan pemasar produk olahan ikan sebagai salah satu oleh-oleh khas Kota Kendari. Metode penentuan contoh dilakukan secara purposive sampling. Kegiatan ini melibatkan dua kelompok mitra yang terdiri dari kelompok nelayan pengolah dan kelompok nelayan tangkap yang masing-masing berjumlah 20 orang. Analisis data dilakukan secara deskriptif dari hasil pelaksanaan dua kegiatan, yaitu kegiatan non fisik (sosialisasi dan penyuluhan) maupun kegiatan fisik (pembuatan demplot pengeringan ikan higienis dan pembuatan burger ikan buntal). Hasil kaji tindak memberikan kontribusi positif bagi penguatan kapasitas kelompok nelayan di bidang ekonomi, ilmu pengetahuan, keterampilan dan sosial budaya. Kontribusi positif lainnya membuka wawasan dan cara berpikir untuk memanfaatkan hasil tangkapan sampingan menjadi produk bernilai jual dan mengolah bahan baku ikan laut dengan cara higienis yang mendukung peningkatan mutu produk untuk diterima di pasaran, serta menciptakan lapangan pekerjaan di desa dengan kemampuan kelompok nelayan dalam berwirausaha secara mandiri, yang pada akhirnya dapat meningkatkan ekonomi rumah tangga nelayan dan membantu program pemerintah dalam pembangunan desa pesisir.
\end{abstract}

Kata kunci: kapasitas kelompok, nelayan, transfer teknologi tepat guna, wirausaha mandiri

\section{ABSTRACT}

Processing of target species do not optimal, especially the processing of the by-catch product. This is caused by the weak capacity of the fishing groups, particularly in the utilization of marine products in the dry season and the acquisition of market information, so it requires increased knowledge and transferal appropriate technology. Purpose of the study: (1) generate a group of fishermen who are skilled, creative and innovative in the processing of marine products; (2) create a group of fishermen who are good entrepreneurs with venture capital is cheap, affordable and sustainable; (3) make the fishing village groups as independent business pioneer advanced and community known as a producer and marketer of processed fish products as one of the typical souvenir of Kendari. Method of determining the sample was done by purposive sampling. This activity involves two groups of partners consisting of fishermen processors groups and fishermen fishing groups each of 20 people. The data were analyzed descriptively of the results of the implementation of the two activities, namely non-physical activities 
(socialization and education) and physical activity (manufacture plots hygienic drying fish and puffer fish burger-making). Action research results make a positive contribution to the strengthening of the capacity of a group of fishermen in the economic, scientific, cultural and social skills. Another positive contribution is opening insights and ways of thinking to make use of by-catch product into marketable products and process raw materials of marine fish with a hygienic manner that supports the improvement of the quality of the product to be accepted in the market, and create jobs in the village with the ability of a group of fishermen in entrepreneurship independent, which in turn can improve the economics of fishing households and assist the government in the construction of coastal villages.

Key words: capacity groups, fishermen, independent entrepreneurs, transfer of appropriate technology

\section{PENDAHULUAN}

Propinsi Sulawesi Tenggara merupakan salah satu propinsi yang memiliki banyak wilayah kepulauan dengan beberapa daerah kabupaten yang juga merupakan himpunan pulau. Beberapa daerah kabupaten tersebut adalah Buton, Muna, Konawe, Kolaka, Wakatobi, Konawe Selatan, Bombana, Kolaka Utara, Kolaka Timur, Konawe Utara, Konawe Kepulauan, Buton Utara dan wilayah kota, yaitu Kota Kendari dan Kota BauBau. Berdasarkan data statistik dari Badan Pusat Statistik Sulawesi Tenggara tahun 2014, bahwa Kabupaten Konawe memiliki luas 579.894 Ha $15,21 \%$ dari luas wilayah Kabupaten Sulawesi Tenggara. Luas wilayah perairan laut (masih termasuk perairan Konawe Selatan, Konawe Utara, dan Konawe Kepulauan) $\pm 11.960 \mathrm{Km}^{2}$ atau 10,87\% dari luas perairan Sulawesi Tenggara.

Jumlah penduduk Kabupaten Konawe berdasarkan hasil proyeksi sensus penduduk tahun 2010, bahwa penduduk Kabupaten Konawe pada tahun 2013 berjumlah 223.727 jiwa yang tersebar dalam 49.733 rumah tangga yang terdiri dari $51,25 \%$ adalah laki-laki dan $48,75 \%$ perempuan (BPS, 2014). Kegiatan perikanan menjadi pekerjaan yang umum dilakukan oleh masyarakat Desa Bokori, terutama kegiatan penangkapan dan budidaya. Hal ini dikarenakan kondisi wilayahnya berada di wilayah pesisir. Kegiatan penangkapan berupa pengoperasian sero, bagan dan pancing, yang kesemuanya menghasilkan produk sampingan yang tidak termanfaatkan. Target tangkapan ikan hanya dipasarkan dalam bentuk segar yang sewaktuwaktu mudah rusak, pengolahannya masih sangat tradisional dan kurang higienis, serta belum berorientasi pasar, utamanya pasar lokal. Padahal jika dikelola dengan baik dan optimal, maka usaha pengolahan ikan dari hasil target tangkapan maupun produk sampingan dari hasil tangkapan, dapat tumbuh dan berkembang secara potensial sebagai salah satu sumber pendapatan alternatif bagi masyarakat nelayan setempat.

Hasil observasi menunjukkan bahwa pengolahan hasil target tangkapan belum optimal dilakukan, apalagi pengolahan terhadap hasil produk sampingan tangkapan. Hal tersebut diakibatkan oleh rendahnya keterampilan dan pengetahuan tentang teknologi pemanfaatan hasil laut, khususnya pada pengolahan dan pengeringan ikan yang berasal dari ikan target maupun produk sampingan hasil tangkapan. Lemahnya keanggotaan kelompok yang menyebabkan kesulitan memperoleh solusi mengenai permasalahan yang dihadapi, terutama suplai bahan baku di musim paceklik dan informasi pemasaran hasil olahan, sehingga sangat dibutuhkan peningkatan ilmu pengetahuan, teknologi tepat guna yang memadai, dan informasi pasar.

Di satu sisi, masyarakat nelayan Desa Bokori juga memiliki minat dan keinginan kuat untuk mengoptimalkan pemanfaatan potensi sumber daya hayati laut di daerah ini. Upaya perwujudannya telah dibentuknya beberapa kelompok nelayan pada tahun 2004, di antaranya yakni Kelompok Usaha Bersama (kegiatan penangkapan) dan Kelompok Langkoe (pengolahan ikan) terdiri dari ibu-ibu rumah tangga nelayan.

Usaha pengolahan yang tengah berjalan baik untuk ikan target maupun hasil sampingan, masih menggunakan sistem tradisional cenderung kurang higienis, sehingga kesulitan menembus pasar/market yang lebih luas, hanya pada pasaran lokal saja. Keterampilan dan pengetahuan yang dimiliki hanya bermodalkan pengalaman saja tanpa ada masukan teknologi. Penguasaan teknologi pengolahan ikan menjadi produk olahan bernilai jual tinggi masih sangat minim, utamanya pengolahan terhadap hasil tangkapan sampingan. Transfer pengetahuan akan metode atau cara pengolahan dan pengawetan ikan yang benar dan higienis diperlukan, agar kelompok nelayan ikan tidak lagi membuang percuma hasil tangkapan sampingannya, tetapi diolah menjadi 
produk bernilai jual, disamping itu hal yang sangat penting dari output kegiatan ini, kelompok nelayan dapat memasarkan produk olahannya secara berkelanjutan, sehingga produksi dari kelompok nelayan terus berlanjut.

Inti dari keterbatasan pengetahuan dan keterampilan tersebut dikarenakan terbatasnya informasi dan teknologi pengeringan (pengawetan) produk ikan yang higienis, serta minimnya pengetahuan nelayan untuk mengolah hasil sampingan dari penangkapan yang terkadang dibuang percuma, tanpa dapat dimanfaatkan menjadi sumber makanan atau produk bernilai jual tinggi, makanan siap saji sehat seperti burger ikan. Dengan mengolah ikan hasil tangkapan sampingan menjadi produk bernilai jual. (Ishak dan Siang, 2014).

Namun dibalik keterbatasan tersebut, terdapat potensi sumber daya manusia (SDM) yang cukup baik, terlihat dari anggota kelompok nelayan yang pernah mengenyam pendidikan formal dari Sekolah Dasar (SD) hingga Sekolah Menengah Atas (SMA), dan sebagian besar anggotanya berada pada usia produktif, serta semangat yang kuat dari kelompok nelayan untuk menjadikan desanya sebagai desa pelopor wirausaha mandiri. Dengan beberapa potensi tersebut diyakini, jika diperkenalkan atau diberikan introduksi pengetahuan dan inovasi teknologi pengawetan maupun pengolahan ikan yang berasal dari produk sampingan tangkapan, maka kelompok nelayan ini mampu mengembangkan potensi dan peluang diri yang dimilikinya. Disamping itu, kegiatan pemasaran produk akan berjalan lancar dikarenakan antara lokasi desa dengan Kota Kendari jaraknya cukup terjangkau \pm $30 \mathrm{Km}$, dengan kondisi jalan beraspal serta ketersediaan bahan baku ikan setiap saat.

Terlaksananya Program Ipteks bagi Masyarakat (IbM) telah memberikan transfer teknologi pengawetan, pengeringan dengan media higienis, murah, dan ramah lingkungan, serta memberikan ilmu baru mengenai cara pengolahan ikan buntal menjadi produk makanan siap saji yang sehat. Ikan buntal jenis $D$. holocanthus merupakan jenis ikan laut yang memiliki bentuk tubuh bulat dengan duri tajam dan banyak di sekeliling tubuhnya. Jenis ikan ini memiliki daging berwarna putih dengan cita rasa khas, gurih, dan tekstur daging yang elastis (Sulistiono et al., 2001). Berdasarkan hasil penelitian mengenai nilai proksimat pada daging ikan buntal yang dilakukan oleh Ishak (2012) diperoleh hasil bahwa kadar protein $17,14 \%$, kadar air $75,59 \%$, lemak $4,14 \%$, serat kasar $0,68 \%$, dan kadar abu $0,24 \%$.

Cita-cita awal yang ingin dicapai melalui kegiatan IbM ini sebagian besar telah terlaksana dengan baik dan sukses, terlihat dari antusias kelompok sasaran dalam menerima masukan metode yang diajarkan, bertindak kreatif menciptakan produk olahan ikan dari bahan baku ikan non ekonomis (think globally, act locally) dan menciptakan kegiatan baru berupa produksi ikan asin higienis dengan kadar keasinan ikan yang sesuai. Ikan sebagai bahan makanan yang mengandung protein tinggi dan mengandung asam amino esensial diperlukan oleh tubuh. Mengkonsumsi ikan sebanyak dua ons dalam sehari telah memenuhi separuh dari kebutuhan harian protein hewani (DKP RI, 2009).

Kegiatan kelompok sasaran tidak berhenti sampai pada terlaksanannya kegiatan IbM, namun tetap berlanjut hingga saat ini, yang ditunjukkan dengan berlanjutnya usaha memproduksi ikan asin memanfaatkan metode pengeringan higienis yang telah diuji cobakan. Terbukti produk tersebut telah dijadikan oleh-oleh khas Kendari yang berasal dari Desa Bokori.

Model kaji-tindak dari kegiatan IbM ini dilakukan dengan tujuan; (1) menghasilkan kelompok nelayan terampil, kreatif dan inovatif dalam mengolah hasil laut; (2) menciptakan kelompok nelayan yang pandai berwirausaha dengan modal usaha murah, terjangkau dan berkelanjutan; (3) menjadikan kelompok nelayan sebagai pelopor usaha mandiri yang maju dan dikenal masyarakat sebagai produsen dan pemasar produk olahan ikan sebagai salah satu oleh-oleh khas Kota Kendari.

\section{METODE PENELITIAN}

Kegiatan ini dilaksanakan di Desa Bokori Kabupaten Konawe Sulawesi Tenggara selama enam bulan (Mei-Oktober 2014). Desa Bokori adalah salah satu desa pesisir di Kabupaten Konawe yang masyarakatnya umumnya bermata pencaharian sebagai nelayan. Usaha yang dilakukan adalah penangkapan ikan, budidaya dan pengolahan ikan.

Kegiatan ini melibatkan dua kelompok mitra yang terdiri dari kelompok langkoe (kelompok nelayan pengolah) dan kelompok usaha bersama (nelayan tangkap) yang masingmasing kelompok berjumlah 20 orang. Kelompok sasaran tersebut berpendidikan Sarjana (S1), Seko- 
lah Menengah Atas (SMA), Sekolah Menengah Pertama (SMP), dan Sekolah Dasar (SD). Penentuan responden dilakukan secara purposive sampling.

Analisis data dilakukan secara deskriptif terhadap hasil pelaksanaan dua kegiatan IbM, yaitu kegiatan non fisik (sosialisasi dan penyuluhan) maupun kegiatan fisik (pembuatan demplot pengeringan ikan higienis dan pembuatan burger ikan buntal).

\section{HASIL DAN PEMBAHASAN}

Penguatan kapasitas kelompok melalui berbagai kegiatan pelatihan dan pendampingan merupakan upaya peningkatan kesejahteraan masyarakat. Kegiatan pengembangan ilmu pengetahuan, teknologi dan seni (IPTEKS) bagi masyarakat ditujukan pada kelompok masyarakat sasaran yang langsung bersentuhan dengan obyek sumber daya alam (SDA).

Penerapan IPTEKS bagi petani-nelayan harus ditingkatkan untuk dapat menjaga kualitas dan kemampuan managerial yang baik agar kontinuitas produksi dan kegiatan selanjutnya dapat dijadikan peluang alternatif peningkatan pendapatannya (Komar, 2001)

Kegiatan IbM yang dilaksanakan di Desa Bokori dengan melibatkan kelompok sasaran dari nelayan penangkap dan nelayan pengolah. Hal ini dilakukan agar terjadi sinergi antara kedua kelompok tersebut. Tugas kelompok sasaran yakni mengolah ikan buntal menjadi produk burger ikan dan membuat media pengeringan higienis untuk pembuatan ikan asin.

Masalah yang mendasari dilakukannya kegiatan ini adalah banyaknya hasil sampingan tangkapan sero yang tidak termanfaatkan. Salah satunya ikan buntal jenis $D$. holocanthus. Jenis ikan ini tidak seperti ikan buntal lainnya yang memiliki racun. Ikan ini tidak beracun dan aman untuk dikonsumsi.Pesisir Bokori menyediakan ikan buntal yang melimpah. Ikan buntal menyebar di seluruh Perairan Indonesia, diantaranya Pulau Weh, Sumatera (Bagan Siapiapi, Sibolga dan Deli), Pulau Bintang, Pulau Bangka, Jawa (Jakarta, Karawang, Cilacap, Semarang dan Surabaya), Pulau Madura, Pulau Kalimantan (Sandakan, Pemangkat, Singkawang, Pontianak, Sungai Duri, Sungai Kapuas, Banjarmasin dan Sungai Mahakam). Selain Indonesia ikan ini juga terdapat di berbagai negara di dunia, antara lain India, Srilangka, Andaman, Thailand dan Singapura (Weber dan de Beaufort, 1962; Sulistiono, 1989).
Masalah lain minimnya pengetahuan nelayan dalam pengolahan ikan asin. Nelayan biasanya melakukan penjemuran ikan dengan memanfaatkan media yang tidak higienis, sehingga memudahkan produknya dihinggapi lalat. Kedua masalah tersebut menjadi alasan penting untuk melakukan kegiatan ini.

Luaran yang dihasilkan sesuai dengan rencana kegiatan adalah:

1. Media para-para higienis sebagai media pengeringan ikan higienis, membantu nelayan dalam memperoleh produk ikan asin bermutu baik, terjangkau, ramah lingkungan dan terhindar dari gangguan telur lalat.

2. Pembuatan Burger ikan dari ikan non target (ikan sampingan hasil penangkapan) yang gurih, bergizi, bebas dari Monosodium Glutamat (MSG) dan pengawet.

3. Modal usaha berkelanjutan, bahan baku pembuatan burger berasal dari ikan tangkapan sampingan yang tersedia secara terus menerus, sehingga menjamin suksesnya diversifikasi pekerjaan nelayan ketika tiba musim paceklik.

Kegiatan yang telah dilaksanakan antara lain:

1. Kegiatan Non Fisik

Pelaksanaan kegiatan non fisik meliputi sosialisasi, penyuluhan dan pembimbingan teknis sebagai sarana transfer informasi pengetahuan dan teknologi kepada kelompok sasaran. Metode pelaksanaan penyuluhan dan sosialisasi dilakukan secara massal. Materi yang diberikan berupa materi yang berkaitan dengan penerapan teknologi pengolahan, pengawetan ikan dan pemasaran produk berikut:

a. Pengenalan jenis ikan yang termasuk hasil produk sampingan dari hasil tangkapan nelayan dan termasuk ikan non ekonomis penting, misalnya ikan buntal/ikan durian jenis D. holocanthus (Ishak, 2012).

b. Pengetahuan akan nilai gizi yang dimiliki oleh ikan buntal/ikan durian jenis $D$. holocanthus.

c. Penerapan metode perendaman dan pengeringan ikan asin yang higienis.

d. Bentuk pengolahan ikan menjadi burger ikan yang sehat.

e. Materi mengenai manajemen usaha dan pemasaran produk olahan hasil produksi kelompok usaha yang benar dan berkelanjutan.

f. Pengelolaan kelembangaan dalam kelompok.

Demi memudahkan kelompok sasaran dalam memahami teknologi yang diperkenalkan kepadanya, baik kegiatan sosialisasi dan 
demonstration plot (Demplot) maka diberikan alat bantu berupa brosur, leaflet, dan resep pembuatan burger ikan.

\section{Kegiatan Fisik}

Pelaksanaan kegiatan fisik melalui pembuatan demplot dan pendampingan dengan pendekatan partisipatif. Beberapa hal yang dilakukan sebagai berikut:

Kegiatan Fisik I:

a. Simulasi pembuatan burger ikan dari bahan baku ikan buntal jenis $D$. holocanthus.

b. Pengenalan cara pengemasan produk roti burger dan daging burger.

Kegiatan Fisik II:

a. Pembuatan para-para hegienis pengeringan ikan asin.

b. Metode atau cara membersihkan ikan yang tepat untuk diolah menjadi ikan asin.

c. Demplot perendaman ikan asin yang higienis dan benar dengan kadar keasinan ikan yang tepat.

d. Demplot pengeringan ikan higienis bebas dari lalat.

e. Teknik pengemasan produk olahan ikan asin.

Pembuatan media pengeringan ikan higienis (para-para higienis) dan proses pembuatan Burger dari bahan ikan buntal jenis Diodon holocanthus, secara rinci disajikan pada Lampiran 1 dan 2.

Teknik atau metode penggaraman yang digunakan yakni penggaraman basah (wet salting) menggunakan larutan garam 30-50\% (setiap 100 liter larutan garam berisi $30-50 \mathrm{~kg}$ garam) (Adawyah, 2011).

Keuntungan penerapan teknologi pengeringan dengan metode para-para higienis ini, dapat diperoleh produk ikan asin yang bermutu, terhindar dari lalat, dan dapat diperoleh produk yang kadar garam di bawah $40 \%$ dengan waktu pengeringan selama satu hari atau sekitar 8 jam. Berbeda dengan Susianawati et al (2007), untuk mendapatkan ikan asin dengan kadar air di bawah ambang batas $40 \%$, perlu dilakukan pengeringan yang lama dengan intensitas sinar matahari mencapai 8 jam/hari dengan waktu pengeringan tiga hari berturut-turut dan perlu memperhatikan dan mempertahankan pengepakan dan penyimpanan yang baik.

Berdasarkan kegiatan non fisik dan fisik yang telah dilakukan, maka diperoleh pencapaian hasil dari kegiatan tersebut, diantaranya (a) kelompok nelayan target tidak mengetahui cara/metode yang benar dan higienis dalam mengolah dan mengawetkan ikan asin, (b) kelompok nelayan target tidak mengetahui proses pengolahan ikan dari hasil tangkapan sampingan, (c) kelompok nelayan target kurang mengetahui metode pengemasan dan cara memasarkan produk hasil produksi kelompok, dan (d) kelompok nelayan target belum memiliki usaha.

Setelah kegiatan IbM, maka beberapa indikator pencapaian target; (a) kelompok nelayan target mengetahui cara/metode yang benar dan higienis dalam mengolah dan mengawetkan ikan asin, (b) kelompok nelayan target mengetahui dan terampil membuat produk olahan ikan buntal menjadi burger sehat dan bergizi, (c) kelompok nelayan target telah terampil dalam mengemas produk, dan (d) kelompok sasaran memiliki usaha memproduksi ikan asin dengan memanfaatkan media pengeringan yang telah diujicobakan dan kelompok nelayan target mampu mengelola usaha yang terarah dan berorientasi pada keuntungan yang berkelanjutan; (2) Output akhir program awalnya pendapatan kelompok nelayan target sangat rendah dibawah UMR (upah minimum regional), setelah kegiatan IbM maka pendapatan kelompok nelayan target mulai meningkat (sama dan atau diatas UMR).

\section{KESIMPULAN}

Kemajuan yang diperoleh hingga saat ini dengan memperkenalkan beberapa metode telah memberikan kontribusi positif bagi kelompok sasaran utamanya, yaitu kontribusi di bidang ekonomi, ilmu pengetahuan, keterampilan bahkan sosial budaya. Salah satu kontribusi positif yang diperoleh adalah membuka wawasan dan cara berpikir kelompok nelayan memanfaatkan hasil sampingan tangkapan menjadi produk bernilai jual dan mengolah bahan baku ikan laut seefektif mungkin dengan cara-cara higienis yang mendukung peningkatan mutu produk untuk diterima di pasaran. Menciptakan lapangan pekerjaan di desa dengan kemampuan kelompok nelayan dalam berwirausaha secara mandiri, yang pada akhirnya dapat meningkatkan ekonomi rumah tangga dan membantu program pemerintah dalam pembangunan desa pesisir. 


\section{UCAPAN TERIMA KASIH}

Terima kasih kami ucapkan kepada Lembaga Penelitian dan Pengabdian pada Masyarakat Dirjen Dikti Kemendikbud atas dukungan dana untuk pelaksanaan kegiatan IbM. Apresiasi terhadap antusias kelompok nelayan dan kelompok pengolah dalam menerima transfer pengetahuan dan keterampilan dari tim $\mathrm{IbM}$, semoga dapat dihargai dengan cara memberikan kepadanya ruang berkreasi dan berusaha seluasluasnya, yang tentunya dapat mendukung usahanya untuk berkembang menjadi lebih baik di masa mendatang.

\section{DAFTAR PUSTAKA}

Adawyah, R. 2011. Pengolahan dan Pengawetan Ikan. Bumi Aksara.

Departemen Kelautan dan Perikanan (DKP) RI. 2009. Fishcake Peluang Alternatif. Majalah Warta Pasar Ikan. Edisi September 2009. Volume 73. Direktorat Pemasaran Dalam Negeri. Departemen Jenderal Pengolahan dan Pemasaran Hasil Perikanan. Departemen Kelautan dan Perikanan.

Badan Pusat Statistik (BPS). 2014. Statistik Daerah Kabupaten Konawe Provinsi Sulawesi Tenggara. Kendari.

Ishak, E. 2012. Biologi Reproduksi Ikan Buntal jenis D. holocanthus di Perairan Desa Bokori
Kabupaten Konawe Sulawesi Tenggara. Jurnal Aquahayati, 8 (2): 069-070.

Ishak, E. dan Siang, R. D. 2014. Ipteks bagi Masyarakat (IbM) Kelompok Nelayan dan Pengolah Ikan Laut Desa Bokori. Laporan Pengabdian. Lembaga Pengabdian Kepada Masyarakat Universitas Halu Oleo. Kendari

Komar, N. 2001. Penerapan Pengasap Ikan Laut Bahan-Bakar Tempurung Kelapa. Jurnal Teknologi Pertanian, 2 (1): 58-67. Jurusan Teknik Pertanian, Fakultas Teknologi Pertanian, Universitas Brawijaya.

Sulistiono. 1989. Fauna Ikan-Ikan Liar di Daerah Pertambakan, Kecamatan Pedes, Kabupaten Karawang. Praktek Keterampilan Lapang. Fakultas Perikanan dan Ilmu Kelautan. Institut Pertanian Bogor. 256 hal.

Sulistiono, Hastuti, K.T, Riani, E, dan Watanabe, S. 2001. Kematangan Gonad Beberapa Jenis Ikan Buntal (Tetraodon lunaris, T. fluviatilis, T. reticularis) di Perairan Ujung Pangkah, Jawa Timur. Jurnal Iktiologi Indonesia. 1 (2): 25-30.

Susianawati, R., Sya'rani, L, dan Agustini, T.W. 2007. Kajian penerapan GMP dan SSOP pada produk ikan asin kering dalam upaya peningkatan keamanan pangan di Kabupaten Kendal. Jurnal Pasir Laut, 2 (2): 40-53.

Weber, M. And L.F.de. Beaufort. 1962. The fishes of the Indo-Australia Archipelago. X. Leiden E.J. Brill. 423p. 
Lampiran 1. Tahap-tahap pembuatan para-para pengeringan ikan asin (para-para higienis)

Tahap 1

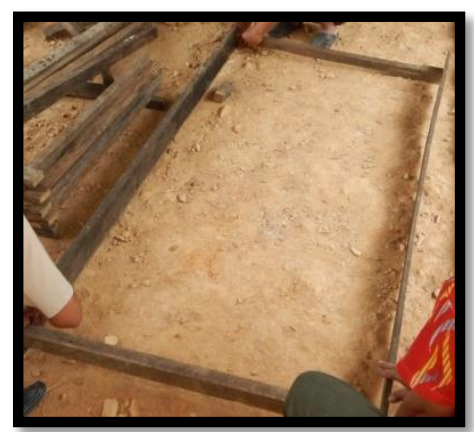

a. Kerangka penutup media b. Model penutup media

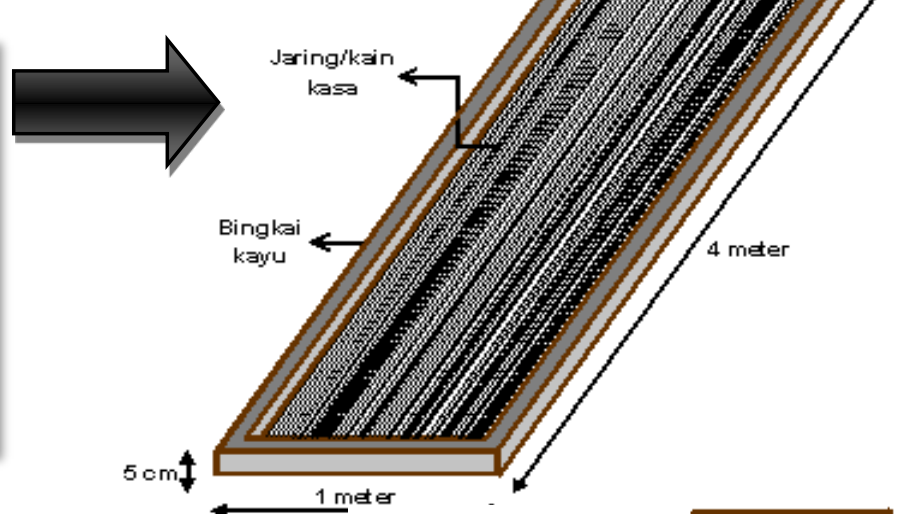

\section{Tahap 2}

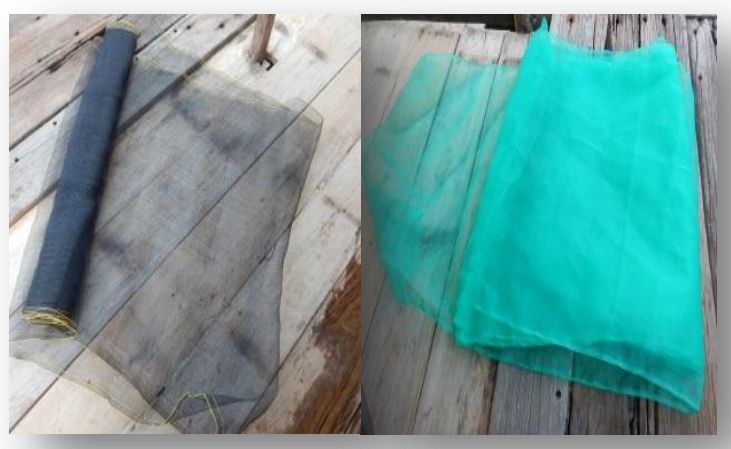

c. Bahan (waring) media

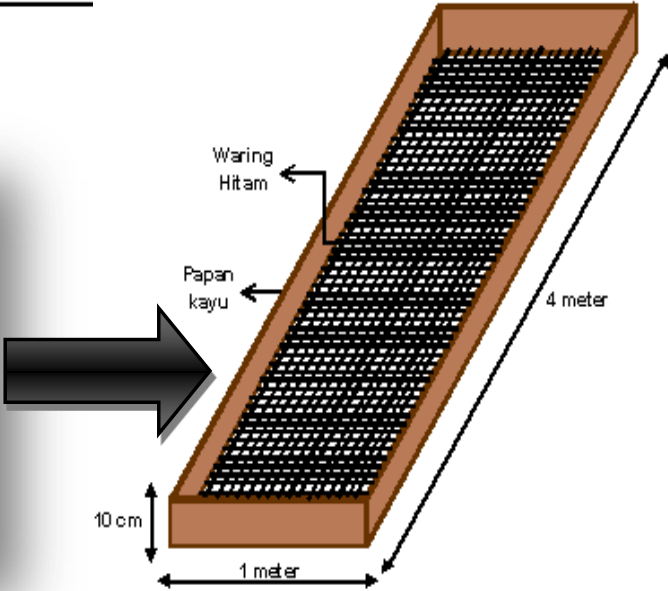

d. Dulang media pengeringan ikan

\section{Tahap 3}

e. Rangka rak dan dulang pengeringan ikan
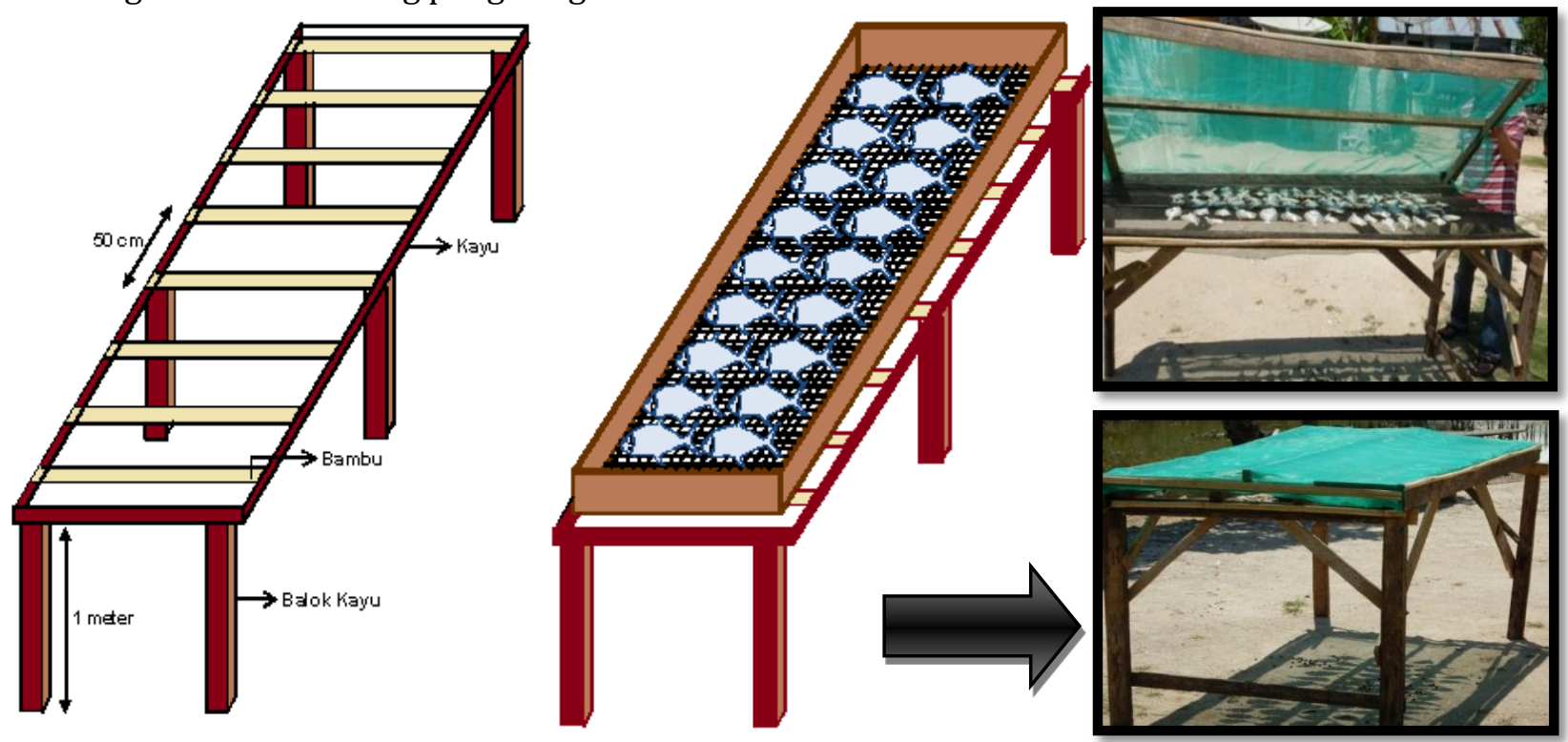

f. Model Rak dan dulang pengeringan ikan (Ishak dan Siang, 2014) 
Lampiran 2. Diagram pembuatan burger ikan buntal jenis D. holocanthus

a. Pembuatan daging burger

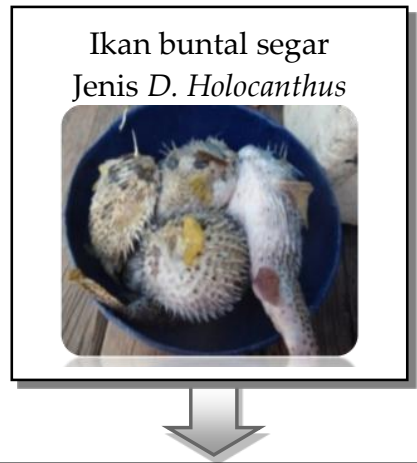

Ikan buntal disiangi, dipisahkan antara daging dengan tulang dan kulitnya, lalu dicuci bersih

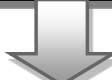

Daging ikan dihaluskan dengan menggunakan alat penggilingan daging.

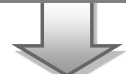

Daging ikan ditambah tepung panir, telur, susu, bawang bombay, gula pasir, garam, pala dan merica, lalu campur sampai homooen

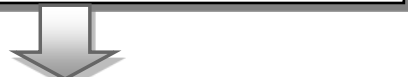

Bentuk bulat panjang dengan diameter 5 $\mathrm{cm}$, bungkus dengan aluminium foil, dan kukus selama 30 menit sampai matang.

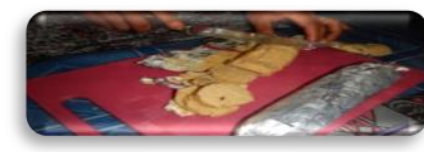

Potong-potong setebal $0,7 \mathrm{~cm}$, lau tumis sampai berubah warna sebagai bahan lapisan isi burger. Atau dikemas seperti pada gambar.

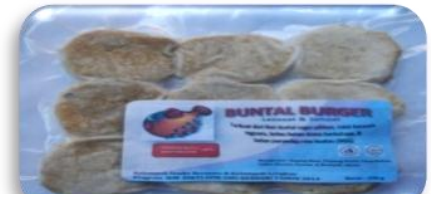

\section{b. Pembuatan roti burger}

Campur tepung terigu, gula pasir, ragi instan dan susu bubuk, lalu aduk rata. Masukkan telur\& air es sedikit demi sedikit dan diuleni sampai kalis.

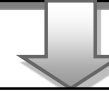

Beri mentega dan garam. Uleni

dankempiskan adonan. Timbanng masingmasing 30 gram dan bulatkan, lalu diamkan 10 menit.

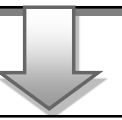

Bentuk adonan menjadi bulat, letakkan di loyang, pipihkan sedikit, dan diamkan selama 75 menit, lalu beri bahan olesan dan taburi wijen.

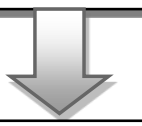

Oven selama 15 menit dengan suhu 190 derajat celcius sampai matang.

Belah roti menjadi dua bagian dan beri bahan isi berupa burger ikan, saus dan bahan pelengkap lainnya.

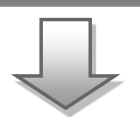

Burger ikan buntal dengan roti burger. Makanan cepat saji yang sehat, bebas MSG \& pengawet.

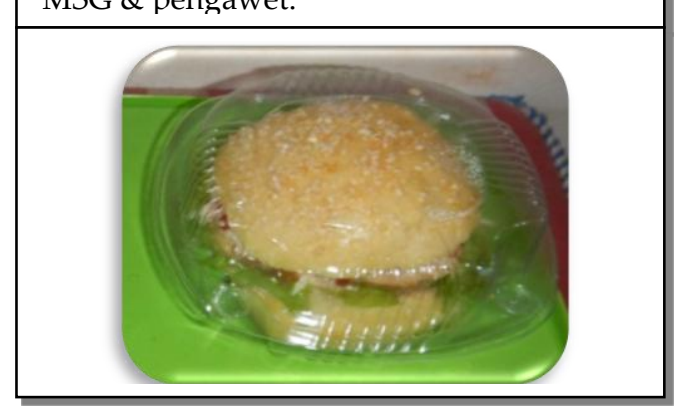

